\title{
Constructing English Reading and Writing Learning and Teaching Mode for Senior High Hearing Impaired Students and Teachers on the Basis of New Media
}

\author{
$\mathrm{Bo} \mathrm{Xu}^{1}$ \\ ${ }^{1}$ School of Foreign Languages, Leshan Normal University, Leshan, Sichuan, China \\ Correspondence: Bo Xu, School of Foreign Languages, Leshan Normal University, Leshan, Sichuan, China. \\ E-mail: 419934369@qq.com
}

Received: August 16, 2018 Accepted: September 18, 2018 Online Published: September 21, 2018

doi: 10.5539/elt.v11n10p113 URL: http://doi.org/10.5539/elt.v11n10p113

\begin{abstract}
New media is widely used in English teaching and learning, special education, in particular. In the new settings, hearing impaired students' learning features are individualized learning style, visual-based learning mode, weakness in understanding and laziness in learning. It is easy for hearing impaired students to learn English via micro course of American Sign Language, English reading and writing. Students learning process is divided into three stages: pre-class: micro-course learning; while-class: cooperative learning in groups; post-class: extensive reading for writing. Finally, English reading and writing learning and teaching mode is constructed on the basis of new media.
\end{abstract}

Keywords: English reading and writing, learning and teaching mode, senior high hearing impaired students, new media

\section{Introduction}

Hearing impaired person is also called deaf or hearing handicapped person. There has been a controversy in oral English teaching and sign language teaching in deaf education field. Many scholars in China have made attempts to teach hearing impaired students by using ordinary English teaching methods. However, it is very difficult for them to overcome vocabulary memory blur. They, sometimes, make incomplete sentence, lack learning motive and have bad learning habits.

English learning mode for hearing impaired person is different from a healthy person. Sign language is the first language for a hearing impaired person, and Chinese the second, English the third. Sign language, Chinese and English have different grammar and vocabulary. For hearing impaired students learning English involves tri-linguistic environment: they have to switch among written Chinese, Chinese sign language and English. Chinese written language and sign language are the interlanguage. Due to limit of hearing, hearing impaired student learns English through visual input and written output. Written English is the focus for teaching and learning.

There are lots of problems in current learning and teaching mode for senior high hearing impaired students. Teacher plays a dominant role in traditional teaching mode. Senior high hearing impaired students are not interested in traditional English teaching and learning mode. In other words, current English learning and teaching mode cannot meet their demands, so, it is urgent that we should construct a new mode for them on the basis of new media.

Students in special education school have their own features: they learn English through reading and writing. Teachers teach English through reading and writing and thus traditional teaching mode is used in classroom. Currently, China and Sichuan province attach great importance to special education. This paper aims to expand learning mode for hearing impaired students via multimedia, MOOC, We-Chat, micro-blog and QQ to reform and innovate teaching mode for hearing impaired students. This paper also attempts to provide a theoretical base and guidance for hearing impaired students' English reading and writing learning mode and reading and writing teaching for teachers in special education school. 


\section{Literature Review}

Both Chinese and foreign scholars have made a study of English teaching for hearing impaired students. Others studied English learning for hearing impaired students.

Sun (2012) deemed that the application of multimedia to special education English teaching can effectively compensate for their hearing and thus can overcome their sense of inferiority and develop students logical thinking ability. Multimedia technology offers a digital learning environment for English learning through the extension of students' visual organs, highlighting the function of direct teaching, thus improve students' self-learning ability. However, we should also pay attention to the negative effects produced by multimedia technology when using multimedia to arouse students' interests.

Song (2012) applied interactive electronic whiteboard to English teaching for hearing impaired students. He put forward advantages and features of interactive electronic whiteboard in teaching design, class interactivity and effective encouragement.

Zhu and Xin (2013a) proved that virtual reality technology can give full play to hearing impaired students visual compensation through the application of virtual reality technology into English learning project for going abroad, which aroused students learning interest and improved teaching quality and thus was of great exploration significance to the reform of teaching mode for hearing impaired students.

Zou (2014) thought that traditional English teaching mode couldn't meet the needs of the era; it is of theoretical significance to conduct an innovative research of teaching mode in the new media epoch. Only teaching reform can meet the demand of the modern era. He made an analysis of the limitations of traditional English teaching mode and discussed the advantage in the new media age and thus put forward relevant strategies.

Based on the application value of new media in English teaching, Chen (2015) explored mutual interactive teaching form and blended modern teaching mode and thus put forward English education innovation strategy, which unified new media and English education. Finally, modernization development of English education is achieved.

Zhou and Hu (2015) introduced current situation of higher special education in China, elaborating the necessity for offering English courses for hearing impaired students and the application of multimedia network teaching in higher education for hearing impaired students, and the advantages of multimedia assisted English instruction for hearing impaired students.

Zhu and Xin (2013b) discussed situational English teaching and made an analysis of leaning features of hearing impaired students. Based on theory and characteristics of virtual modern technology, they expounded the construction of immersive virtual situational teaching and the application of virtual modern technology to tourism English situational teaching for hearing impaired students.

Yu (2015) pointed out that effective and fast digital technology and mobile teaching mode can help hearing impaired students to get out of the time and space limitation so that vividness, interactivity and autonomy in English class can be achieved, bringing totally new experience for English learning.

Zhou (2016) integrated network information technology with English extracurricular reading through guiding hearing impaired students autonomous reading and facilitating their reading strategy. Hence, hearing impaired students learn English by doing, which reflects the significance of English teaching in special education.

Scholars in China mainly applied multimedia, whiteboard, VR and situational teaching to English teaching for hearing impaired students, which put emphasis on teaching methods and mode. Obviously, to study English reading and writing from the perspective of new media is a new attempt.

Patricia O'Malley et al. (2014) made an investigation on the effects of using iPads in a class-wide academic intervention to increase independent task completion and basic math skills of seven students diagnosed with autism spectrum disorders (ASD) enrolled in a special education school. He also made an analysis of the advantages of and challenges to using iPads for classroom instruction. Traditional basic math instruction was used for the baseline phase, while a basic math skill app on an iPad was used for the intervention phase. Math probes were completed and the results recorded for four to five sessions for each of the four weeks of the study. Data on level of teacher prompting and presence of noncompliant behaviors were collected during every phase. Descriptive and visual analysis techniques were used to analyze the data. Findings suggested iPads can be an effective instructional tool to enhance learning and independence.

Johnson (2013) conducted a research on using tablet computer for students with special needs. Generally speaking, teachers in special education are pessimistic about the value of Ipad to teach English. Teachers hold 
that using Ipad helps improve students reading and writing competence and hence improve their teaching. Tablet computer is essential for an individual's study plan. Special education teachers and teacher assistants reported most students used iPads to promote their language and literacy skills. The most frequently reported benefit of using tablet computers is that it enhanced students' motivation with teacher's instructional plan. Tablet computers has become an essential aspect of individual program plans. Downloading and organizing specific applications on specific children's tablet computers are the teaching task, and the focus of evaluation of tablet application is students' professional development.

Camille and Bruce (2013) discussed using IPad to enhance student's participation in learning, mainly through the number of English and math homework. Students and teachers in the survey are positive about using Ipad to teach English.

From the perspective of research content, scholars in China mainly discussed the application of multimedia, interactive whiteboard, virtual reality technology in English teaching. Some scholars explored the application of digital technology and mobile technology and effective teaching strategies and teaching methods into English teaching for hearing impaired students, others conducted research on teaching grammar, vocabulary and reading. To sum up, previous researches have three shortcomings, the emphasis was put on English teaching not on English learning; the stress was laid on micro-study not on macro-study; the discussion on new media is not sufficient.

\section{English Reading and Writing Learning and Teaching Mode for Hearing Impaired Students and Teachers on the Basis of New Media}

\subsection{Features and Status quo of English Reading and Writing for Hearing Impaired Students}

Hearing impaired students have their own features. They learn English via reading and writing. English teachers teach students through reading and writing and the teaching method is very traditional. The current study holds that the features of hearing impaired students include: individualized learning style, visual-based learning mode, weakness in understanding and laziness in learning.

\subsubsection{Individualized Learning Style}

Individualized learning style refers to the autonomy, the ability to explore new things and the ability to cooperate with people. Hearing impaired students like to communicate with others through sign language and written language. For instance, some students like to answer questions through written language or sign language. Some students like to meditate in class and take notes. Others have a strong learning autonomy and acquire knowledge from books and teacher's lecture. Still others have a worse learning autonomy and they need teachers' guidance and language learning situation created by the teachers (Ren, 2017).

Hearing impaired students who were born in 1990s are more prone to utilize new media such as mobile phone and portable computer to learn English. Furthermore, they like to use fragmental time such as a period during the two classes, time before lunch or before bedtime to learn English, waiting time for buses or even on the buses. Under this circumstance, hearing impaired students like to make use of new media such as online courses, micro-courses and MOOC to learn English reading and writing.

\subsubsection{Visual-Based Learning Mode}

Words with pictures and real objects are easy for hearing impaired students to learn. Hearing impaired students are easy to understand the meaning of the sentence literally. Sometimes, they can't understand the contents thoroughly. It is difficult for them to understand and use the words with affective meaning. One case is that they master the words, phrases and grammar in grade one; they may forget all of them the next year.

Let's take the phrase "watch out" as an example, it is much easier for ordinary person to know its meaning. They only know the literal meaning: watch out of something. They don't understand the extended meaning "be careful".

\subsubsection{Weakness in Understanding}

For writing, they often use hypothesis and can't understand the real information. They stress one point or topic again and again. Some students turn a blind eye to hypothesis condition. On the vice versa, they write the real information in their writing.

For example, the writing requirements go like this. Suppose you are Li Ming, you take part in an English contest and you win the first prize. Please introduce your English learning methods to your peers. Hearing impaired students will write their real name and tell the fact that they have never participated in an English contest, not to mention won the first prize. As a result, in their writing, they will not mention English learning methods. 


\subsubsection{Laziness in Learning}

Most hearing impaired students are perplexed about their future. The laziness atmosphere in special education school exert a bad influence on them. They are relatively lazy in learning and life, and they are slow in doing things. Generally speaking, students transferred from other school will cherish opportunity to learn English. They are willing to learn English, so they work hard. They make good scores in academic achievements.

On the contrary, those who studied in the special education school from the beginning don't work hard. They have bad learning habits. As a result, their academic performance goes from bad to worse.

As is discussed above, senior high hearing impaired students have the following four features in English learning: individualized learning style; visual-based learning mode; weakness in understanding; laziness in learning. It is obvious that current learning and teaching mode can't meet their needs. Therefore, it is imperative that a new learning and teaching mode should be constructed under the new circumstances.

\subsection{English Reading and Writing Strategies on the Basis of New Media for Hearing Impaired Students and Teachers}

On the basis of interactive mode, we make full use of new media such as multimedia technology, Wechat, MOOC, Micoblog, QQ to train reading and writing competence for hearing impaired students, thus innovating their English learning mode. We put forward three activities: pre-class :developing and utilizing English micro-course resources, while-class: group work constructing new knowledge frame, post-class: extensive reading facilitating writing.

\subsubsection{Pre-class Activity: Developing and Utilizing English Micro-courses Resources}

\section{1). Utilizing American Sign Language Micro-course}

The English class in special education school is not effective because the communication between teacher and students is not smooth. The quality of English class is affected by differences between students and teachers. American sign language is different from English and gesture code English, which has its unique grammar rules. In previous English class, as teachers teach words and sentences, they spend a lot of time on teaching students American sign language, making English class a sign language class. American sign language micro-course is a good network resources. Teachers teach every word, focal sentence pattern and the way to type American sign language. Study shows that students are very interested in teachers micro-courses, which arouses hearing impaired students interests in learning English (Luan, 2016). Other sign language includes: http://www.csl-press.com/aboutus/.

It includes sign language TV program, sign language MV, deaf person's movie, deaf person's culture, sign language teaching, which offers deaf culture and news for deaf person and sign language lovers. American sign language website : http://www.lifeprint.com/index.htm.

2). Developing and Utilizing English Reading and Writing Micro-course

On the one hand, teachers can make use of micro-course online, for example: reading and writing micro-course made by QQ company. Typical website is https://ke.qq.com/course/180334?from=15. On the other hand, teacher can record reading and writing micro-course themselves. After the course is recorded, teachers need to add new resources to the course, such as exercises, homework and further reading materials, etc. With these online courses, hearing impaired students can use the courses repeatedly. They can also communicate with teachers online and offline.

For each class, teacher assigns a task before class. Students do the preview work online and ask questions in class.

\subsubsection{While-Class Activity: Cooperative Learning}

In teaching reading and writing, for a class with 12 students, teachers can divide the whole class into four groups with three students in one group. Each group focuses on one topic: How to keep healthy, my hometown, how to learn English, etc. Students in each group write a topic. Within a group, one student develops a paragraph, starting with a topic sentence. The other two students take turns to write the rest paragraphs. At last, one student summarizes the whole writing and organize them into one composition and share the composition with the other two students. If one of the student makes correction, he or she can correct them in bold characters.

We selected three sample writings of hearing impaired students from Leshan Special Education Senior high Grade 2. 
Sample 1 . How to keep healthy

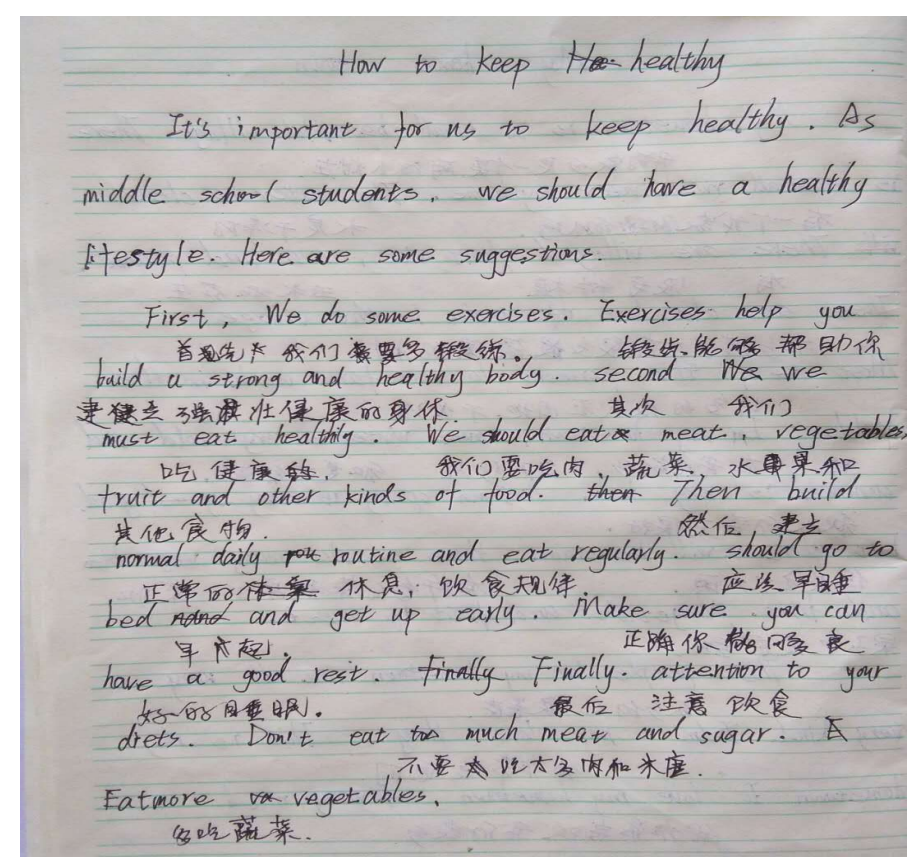

Sample 2. Writing a letter to tell how to learn English

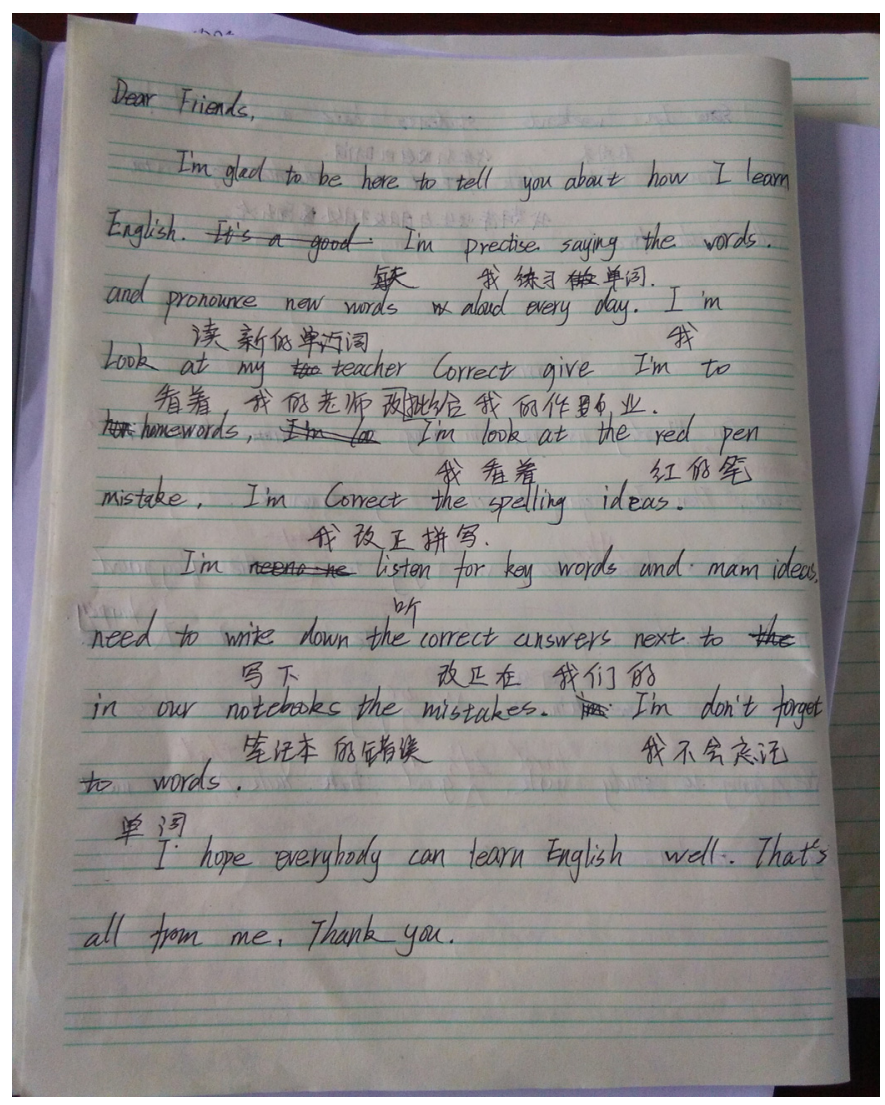


Sample 3. My hometown

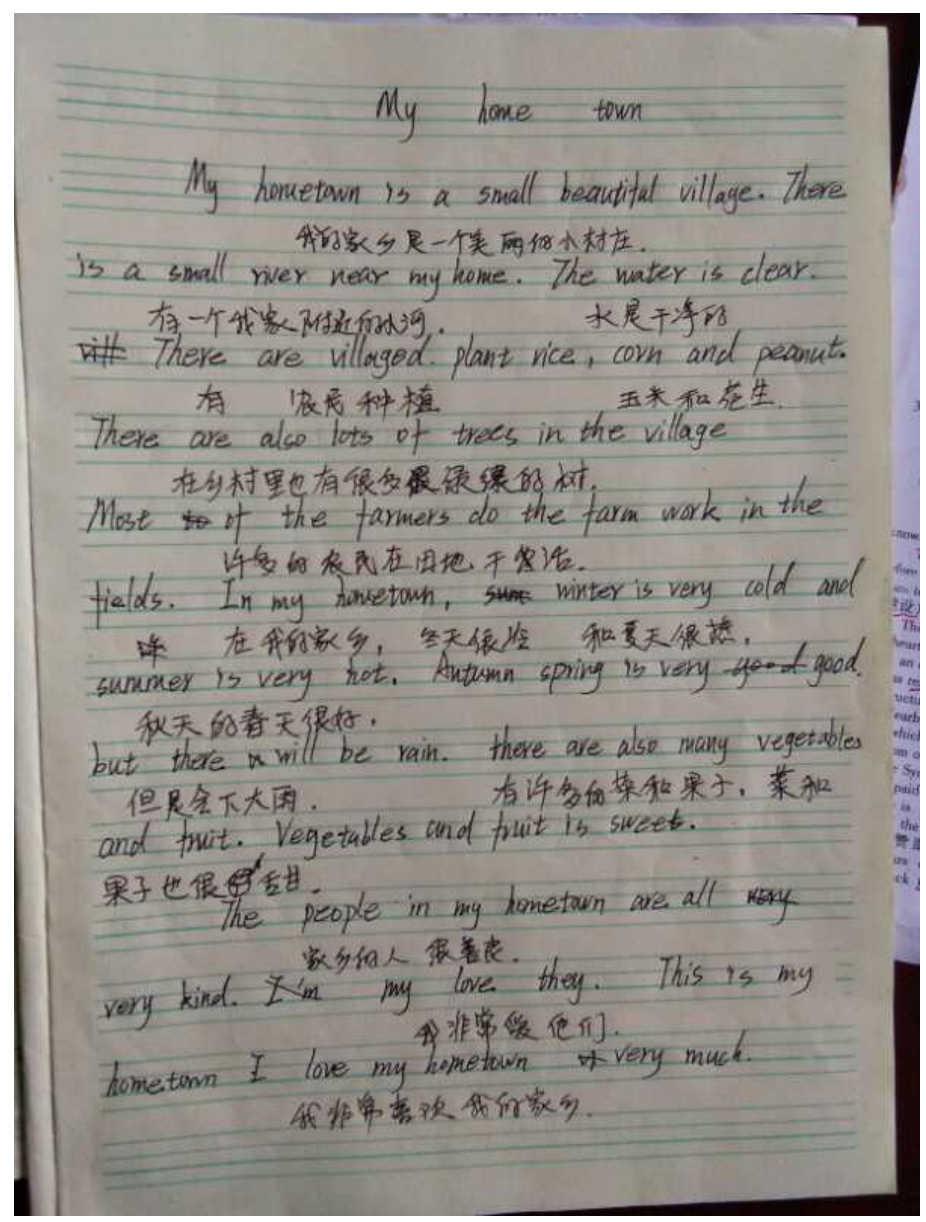

\subsubsection{Post-class Activity: Reading for Writing}

For post-class activity, teachers assign students some reading and writing homework. As is known to all, reading is language input while writing is language output. As a learner reads more, he or she will know more vocabularies and sentence patterns. In writing, a learner will put what he or she reads into writing. Hence, reading is quite important for a learner.

Relevant extensive reading will facilitate students writing and what's more, further reading will help hearing impaired students to revise their writing.

3.2.4 An Interactive Learning and Teaching Mode Between Teacher and Hearing Impaired Students

In general, based on micro-course platform, cooperative learning in groups and extensive reading for writing, a reading and writing mode for hearing impaired students is constructed and illustrated as follows: 


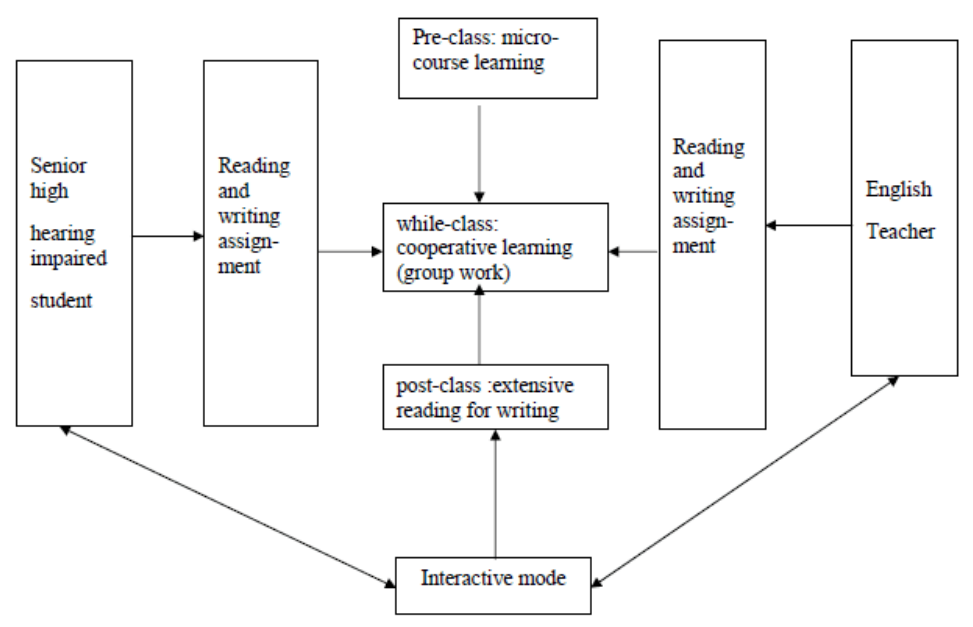

For this mode, we take writing topic "How to keep healthy" as an example to illustrate the three stages:

Pre-class stage: micro-course learning. Teachers assign students with a writing topic "How to keep healthy". Students search the topic online to find relevant micro-course and watch it to find the various ways to keep healthy. The following website is a good example to watch. https://www.iqiyi.com/w_19rulzvg7l.html.

While-class stage: cooperative learning (group work). The writing topic is how to keep healthy. Within a group, one student develops a paragraph, starting with a topic sentence: "It is important for us to keep healthy. As middle school students, we should have a healthy lifestyle. Here are some suggestions."

The other two students take turns to write the rest paragraphs. "First, we do some exercises; Second, we must eat healthily; Then, build a normal daily routine and eat regularly; Finally, pay attention to your diets".

In the end, one student summarizes the whole writing and organize them into one composition and discuss the composition with the other two students. If one of the students makes correction, he or she can correct them in bold characters.

Post-class stage: extensive reading for writing. Teacher can assign an extensive reading material about how to keep healthy, such as some sample writings in the website: https://mip.ppzuowen.com/en/163197.html. After students read the sample writing about how to keep healthy, teachers ask them to correct their own writing by the peers in their group. Finally, they have their revised writing work handed in.

\section{Discussion}

Nowadays, new media has been widely used in English teaching and learning, especially in special education. It is becoming a trend that students are widely exposed to micro-course, MOOCs and many other online courses. Thus, making good using of online courses is a must for hearing impaired students.

In modern education technology settings, studies show that hearing impaired students' learning features are individualized learning style, visual-based learning mode, weakness in understanding and laziness in learning English. It is easy for hearing impaired students to learn English via micro-course of American Sign Language, English reading and writing, wechat, IPads, micro-blog, and other online resources etc. Consequently, students learning process is divided into three stages: pre-class: micro-course learning; while-class: cooperative learning in groups and post-class: extensive reading for writing. Finally, English reading and writing learning and teaching mode is constructed on the basis of new media.

However, every coin has two sides. Although teachers in special education school are positive about hearing impaired students' using new media in English learning, some students will not make good use of new media, to name only a few, using iPad and mobile to play games. However, these problems will be solved through teacher's continuous guidance and instruction. As a whole, the time hearing impaired students spent on leaning English is much more than the time they spent on playing games. So, new media brings them blessing not curse.

\section{Acknowledgements}

This paper is supported by a grant from "Scientific Research Development Plan Project, Leshan Normal University" (Project name: A Study on the Training of English Reading and Writing Competence for Hearing Impaired Student on the Basis of New Media; Project number: S16015). This paper is also supported by a grant 
from Sichuan Social Science Planning Office,(Project name: A Study on the Learning Mode of English Reading and Writing for Hearing Impaired Student on the Basis of New Media_-Taking Senior High Students in Leshan Special Education School as an Example, Project number SC17XK031).

\section{References}

Camille, R., \& Bruce, R. (2013). Using IPADS to Assist Students with Special Needs: A Preliminary Overreview (pp. 176-178). Special Education Apps, Proceedings of the Southern Association for Information Systems Conference, Savannah, GA, USA.

Chen, R. J. (2015). On the Creativity of English Education in the Era of New Media. Journal of Inner Mongolia Normal University (Educational Science), 10, 133-134.

Genevieve, M. J. (2013). Using Tablet Computers with Elementary School Students with Special Needs: The Practices and Perceptions of Special Education Teachers and Teacher Assistants.Canadian Journal of Learning and Technology, 39(4), 1-12.

Luan, S. H. (2016). Mobile Internet Micro course platform: Constructing a New Teachign Mode for Hearing Impaired Students. Modern Special Educatio, 7, 53-55.

Patricia O'Malley. (2014). Effectiveness of Using iPads to Increase Academic Task Completion by Students with Autism. Universal Journal of Educational Research, 1, 90-97.

Ren, H. F. (2017). Individualized English Learning for Hearing Impaired Students on the Basis of Electronic Schoolbag. Cultural and Educational Materials, 5, 234-235;227.

Song, B. (2012). The Application of Interactive Whiteboard Deaf School English Teaching. China Educational Technology and Equipment, 6, 23-24.

Sun, Z. F., Hu, H. Y., \& Zhou, B. C. (2012). Effective Combination of Multimedia Technology and Deaf and Dumb Students' English Learning. China Educational Technology and Equipment, 2, 126-130.

Yu, J. (2015). On the English Teaching in Deaf School in the Environment of Mobile Terminal. A Journal of Modern Special Education, 11, 56-58.

Zhao, C. H., \& Hu, Z. B. (2015). The Current Situation of Born Deaf English Learning and the Use of the Multimedia Technology in China. Journal of Jilin Jianzhu University, 4, 99-101.

Zhou, L. (2016). Using Internet to Open Another Window of English Reading for Hearing Impaired Students. Zhejiang Educational Technology, 1, 42-43.

Zhu, L., \& Xin, W. (2013a). The Application and Practice of Virtual Reality Technology in English Project Learning for Hearing Impaired Students. Journal of Educational Institute of Jilin Province, 6, 153-154.

Zhu, L., \& Xin, W. (2013b). The Application of Virtual Reality Technology in Situational English Teaching for Arts Hearing Impaired Students. Vocational Education Communication, 21, 72-74.

Zou, X. W. (2014). An Innovative Study of Course Teaching Mode for English Major in the Era of New Media. Journal of Inner Mongolia Normal University (Educational Science), 12, 113-114.

\section{Copyrights}

Copyright for this article is retained by the author(s), with first publication rights granted to the journal.

This is an open-access article distributed under the terms and conditions of the Creative Commons Attribution license (http://creativecommons.org/licenses/by/4.0/). 